\title{
A brief history of porcelain enamel: from artistic enamel to technical enamelling
}

\author{
Contributors: , Stefano Rossi ${ }^{1}$, Francesca Russo ${ }^{2}$, Attilio Monzio Compagnoni ${ }^{3}$ \\ 1, Department of Industrial Engineering, University of Trento; stefano.rossi@unitn.it \\ 2, Department of Industrial Engineering, University of Trento; francesca.russo-2@unitn.it \\ 3, Emaylum Italia, Via Località Bedeschi 10a, 24040 Chignolo d'Isola (BG); \\ info@emaylumitalia.it
}

Version received: 7 July 2020

check for updates

Porcelain enamel is a glassy material deposited on a metallic substrate and fired at high temperatures (500-900 $\left.{ }^{\circ} \mathrm{C}\right)$ to form a stable and permanent bond with it through chemical-physical reaction. This coating was developed in ancient times for decorative purposes and it was mainly used to embellish precious objects with colourful and glossy finishing as if to imitate the shining of precious stones. Only from 1760 enamelling of metal objects began to play a technical role. Nowadays vitreous enamel coatings are widely used and appreciated for high-duty technological applications, as they provide good corrosion protection of the covered substrates and they can withstand chemical attack, abrasion, and degradation caused by external agents, maintaining their aesthetical properties unchanged in time. This work is to introduce and describe the history of enamelling from ancient times to the modern era, revealing the glorious past of this material for decorative purposes and its use as a technical coating from the First Industrial Revolution onward.

Enamel coatings are vitreous layers deposited on metallic substrates in order to protect them from external agents and guarantee the protection and aesthetical properties over time. Their optimal protection capabilities are due to the strong adhesion with the metallic substrate [1][2] and the glassy nature of this kind of layer. For these reasons, enamel coatings are widely used in many technical fields [3][4]. Their use as industrial coatings dates back to the $18^{\text {h }}$ century, but their discovery goes back to 5500 years ago.

\section{The origins of enamelling (proto enamel)}

As far as we know, the cradle of enamelling has to be identified in the Mediterranean Sea, between Mycenae and Cyprus about 3500 years ago, as some important archaeological findings were discovered in these places ${ }^{[3]}$. Among the main precursors of porcelain enamel, it is possible to identify the Egyptian faience, a sintered-quartz ceramic in use since the $\mathrm{V}$ millennium $\mathrm{BC}^{[5]}$. The Egyptian faience is a no-clay based ceramic displaying surface vitrification and colours ranging from transparent to turquoise, blue, and green when admixed with copper pigments. It was mainly used to create jewellery and decorative objects by casting in clay moulds. The faience is constituted by finely powdered quartz grains together with a small amount of alkali, calcite lime, and water [5][6]. The heating treatment allows the formation of an inner siliceous and porous body covered by an outer layer of soda-lime glaze. The glossy aspect of faience objects is mainly due to the irregular surface of the crushed siliceous core, which scatters light and makes the object shine [7]. An example of a famous Egyptian faience is showed in Figure 1. 


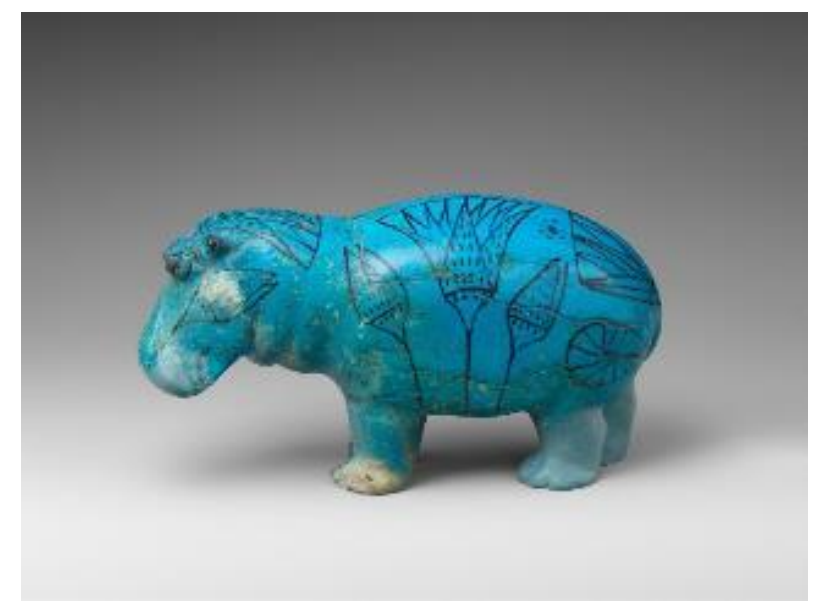

Figure 1: Hippopotamus (“William”), ca. 1961-1878 BC, Egypt, Khashaba excavations 1910, Faience, L. 20; W. 7,5; H. $11.2 \mathrm{~cm}$, The Metropolitan Museum of Art, New York, NY, United States.

The first real enamelled objects were found in Mycenae and are dated around 1425 BC, but the most important findings date back to the Cyprus Golden Age (1500-1200 BC) when the Mycenaeans found refuge on Cyprus island. Some remarkable examples of enamelling development in Cyprus are the Kouklia gold rings (1400 BC) and the Kourion golden royal sceptre (1200 BC) [8]. Both the two art pieces are decorated with coloured enamels arranged in small metallic cells, through a technique, which will be later addressed as "cloisonné" [9]. Unlike the certainties about the existence of enamelling in Cyprus, it is disputed whether enamelling was practised in Egypt towards the $1300 \mathrm{BC}$ or not, as some jewels found in the Tutankhamun tomb seems to be enamelled but no scientific evidences have been gained on this regard ${ }^{[10]}$. On the other side, this hypothesis could be supported by the close commercial relations between Egypt and Cyprus at that time, thus justifying the presence of enamelled items as import goods.

\section{Enamelling techniques over the centuries}

Over the centuries many different enamelling techniques have been developed. In the next paragraphs, we will describe in detail the most important techniques, such as the cloisonné, the champlevé, and the émail paint.

\subsection{The cloisonné technique}

The cloisonné technique is the most ancient enamelling deposition method. The word "cloisonné" derives from the French word "cloison" (originated from the Latin word "clausus" the vitrification of the enamel. The possibility to use metallic strips as expansion joints allowed to create beautiful objects, guaranteeing good adhesion between the enamel and the metallic surface.

The first important cloisonné archaeological findings can be attributed to the Assyrian Empire and are constituted by polychrome bracelets found in the Nimrud tombs [11]. On this regard, it is important to underline that Assyria, around $650 \mathrm{BC}$, controlled territories in which enamelling had already existed (Cyprus, Egypt): both these clues make the hypothesis of the use of porcelain enamel by the Assyrians very realistic. From that moment onwards the cloisonné enamelling technique spread in all the ancient world, mainly following two roads: the first towards the east, along the Silk Road, the latter towards the western Mediterranean Sea. The responsible of the spread towards the east were the Scythians, an Iranian warrior people, who brought the art of enamelling to Iran, Siberia and the Caucasian area, between the $600 \mathrm{BC}$ and the $300 \mathrm{BC}$ [3]. One example of important findings discovered in Ziwiye (Iran) is a gold strip with traces of enamel decorations, conserved at the British Museum (London, UK). Another important example of ancient enamelling art is the "Gold Torque terminating in Scythian horseman", a gold jewel decorated in enamel, found in the Kul-Oba excavations (Black Sea coast) and dated around the 400 BC. The diffusion of the cloisonné enamelling technique towards the west was probably favoured by the Phoenicians. The Phoenician city of Tyre was, for a short time, under the hegemony of the Assyrians, but it also maintained a close business relationship with colonies in Andalusia (Spain) and Magna Grecia [12]. This context probably allowed the diffusion of enamelling in Spain and Italy 


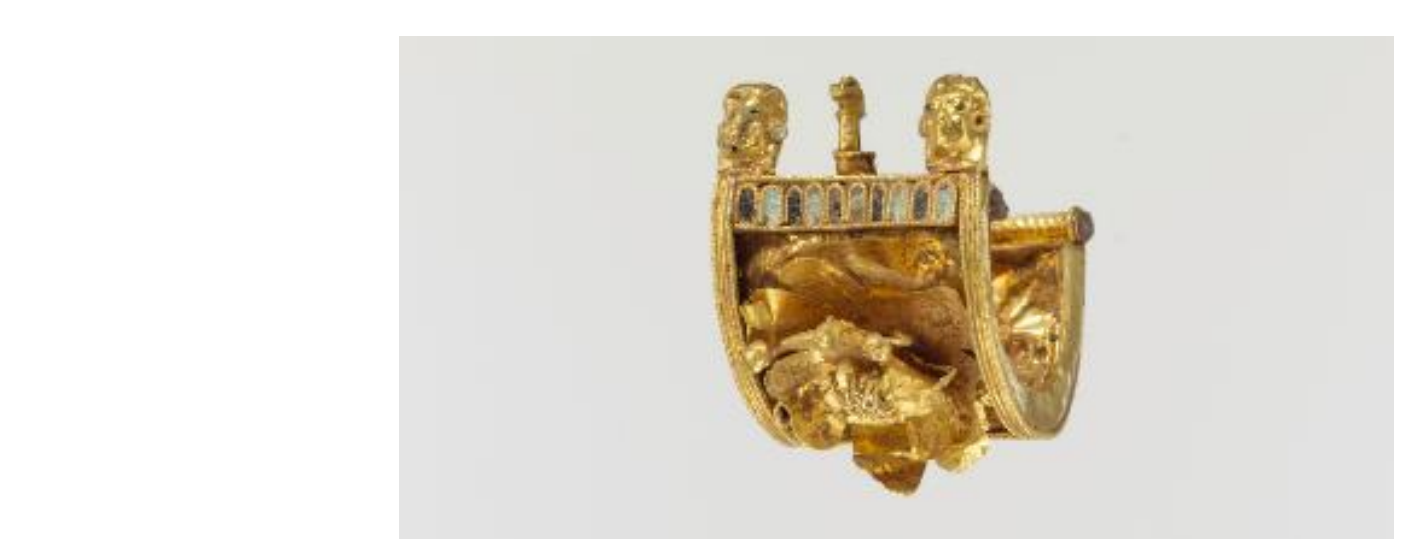

Figure 2: Gold and enamel a baule earring, ca. $6^{\text {th }}$ century BC, Etruscan, diameter $2 \mathrm{~cm}$, The Metropolitan Museum of Art, New York, NY, United States.

After the Sack of Rome (410 AC) and the success of the barbarian invasions, the art of cloisonné enamel suffered a rapid decline. It was only around the $600 \mathrm{AC}$ that Greek cloisonné enamel began to be used again for the decoration of icons, as some findings in Georgia testify [13], and it was in this way that the Byzantine enamel was born. The Byzantine tradition was then acquired by the Germanic peoples, who have left evidence of this decorative art in many findings of inestimable value; just think of the Iron Crown, enamelled under the reign of Theodoric (500 AC) and worn by Charlemagne and other kings up to Napoleon. Between 1000 and 1200 AC the Byzantine tradition then spread in all Europe, from Spain and Italy to France and Germany, giving rise to several artistic schools; its diffusion did not stop in these lands but reached China around the XIV century.

The cloisonne technique was the prevalent enamelling technique until the end of the 1 th century and it was also optimized for the deposition on copper and iron, but, in the following centuries, it was slowly replaced by the "champlevé basse-taille" technique.

\subsection{The champlevé technique}

The champlevé technique is very different from the cloisonné method, as it consists in applying the enamel powder in carvings made on the substrate and then proceed to the firing of the powder to obtain a smooth surface. This technique has been used by the Celts since the $1^{\text {st }}$ century BC to decorate small bronze objects such as brooches and buttons. During the following centuries, a "Gallo-Roman" technique (champlevé on bronze) was developed and the Romans played an important role in the diffusion of bronze enamelling [14]. The champlevé decoration process flourished again only in the last decades of the $11^{\text {th }}$ century when the champlevé enamelling on copper was born in the French town of Conques. In the following years, it spread in all Europe and new schools were born in Liege (Belgium), Cologne (Germany), Silos (Spain) and Limoges (France), all rising along the main arteries of the Camino de Santiago de Compostela. The geographical proximity to this pilgrim route was probably one of the main reasons why most of the enamelled objects had a religious and liturgical character.

One of the most important enamel school, flourished around 1130 in Limoges, was the only artistic school in Europe which survived over the centuries $[15]$. The quality of the handworks reached a level comparable to the beauty of cloisonné enamelled objects, as it can be seen in Figure 3. 


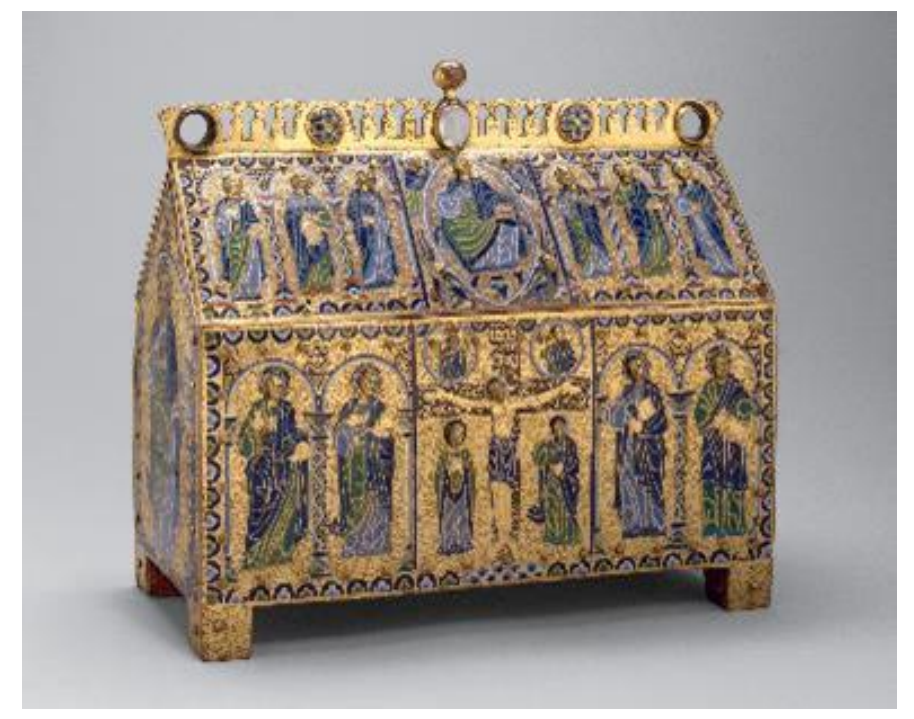

Figure 3: Chasse with the Crucifixion and Christ in Majesty, 1180-1190 AC, Limoges, France, $26.2 \times 30.2 \times 11.6 \mathrm{~cm}$, champlevé enamel on copper, The Metropolitan Museum of Art, New York, NY, United States.

At the beginning of the XIV century, the champlevé method evolved in a new technique, with influences from the Italian cloisonné method: the champlevé basse-taille was born [16]. This technique consisted in making not very deep carvings on the metal substrate and using both coloured and translucent enamels. The application of translucent enamels was mainly made on copper objects covered with a layer of gold or silver. Around the end of the XIV century, this technique was widespread in Spain and also in Iran, where these objects were called "minakari".

\subsection{From the Renaissance onwards}

The decline of the champlevé enamelling started at the end of the XIV century, but only after 100 years it rose up again in Limoges under a different form, called "enamel paint". Enamelled objects had no more a religious character but were mainly committed by rich families as luxurious decorations objects. The technique of enamel paint consisted of using enamel as if it was painted on the substrate, used as a canvas. When we refer to enamel paint is necessary to point out that two different techniques were developed, the first called "grisaille", only using black and white enamel, the other, more general, using coloured and also translucent enamels [17].

The grisaille technique, whose name comes from the French word "gris", consists in the preparation of a background black enamel layer which is subsequently covered with uncooked white enamel. The top white layer is scraped with precision to produce different layers and obtain a wide range of grey shades, thanks to the transparency of the white enamel. This technique was typical at Limoges in the Renaissance period [17]. A similar procedure can be followed to obtain coloured paint enamel, which firstly appeared in Italy and France. A famous example of enamel paint is represented in Figure 4, an artwork from Léonard Limosin, the most important enameller painter of the France Renaissance. 


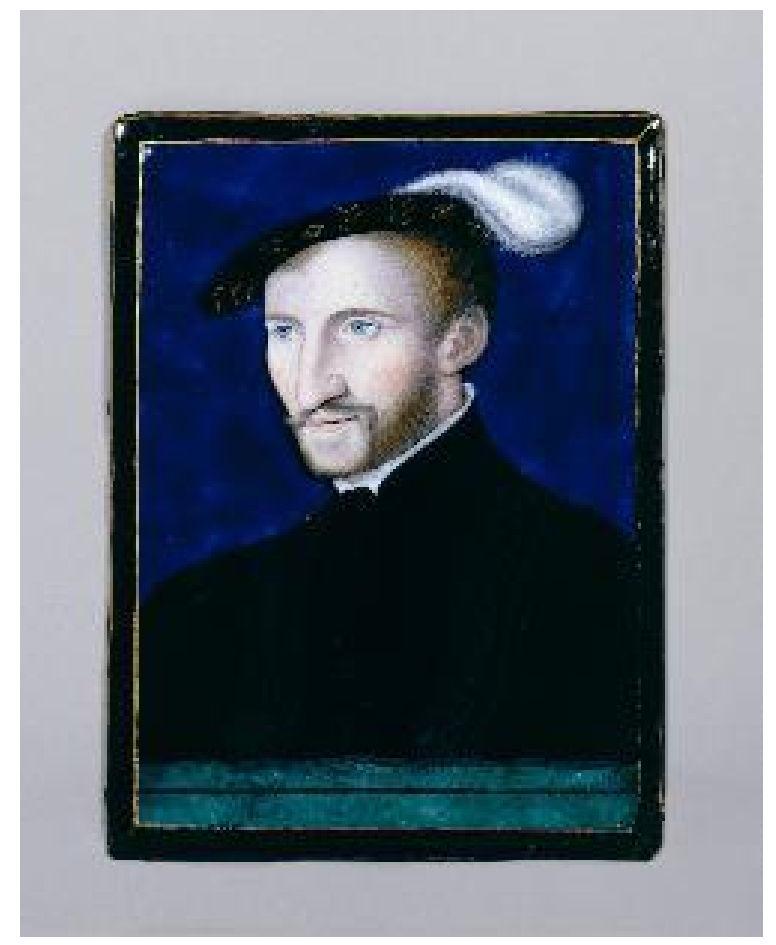

Figure 4: Henri d'Albert, King of Navarre, Léonard Limosin, 1556, enamel painted on copper, $19.1 \times 14.3 \mathrm{~cm}$, The Metropolitan Museum of Art, New York, NY, United States.

Around the $17^{\text {th }}$ and $18^{\text {th }}$ century the production of enamelled objects was relegated to clocks, ornaments and small goods. Between the end of the $19^{\text {th }}$ century and the beginning of the $20^{\text {th }}$ century, artistic enamelling became influenced by the Art \& Craft Movement, and later developments followed the Art Déco and the Art Nouveau. In the $20^{\text {th }}$ century, artistic enamelling had another period of renewed interest thanks to technological developments, such as new kilns and fuels. In addition to that, new colours and finishing were developed, and the overall quality of the objects really improved. Several examples of artistic works produced with different techniques and in different eras can be observed at the Enamel Museum ArTchivio located in Ponte San Pietro (BG, Italy) [18].

\section{The origins and development of technical enamelling}

The transition from artistic to technical enamelling happened gradually and it was favoured by the progress in the metallurgy field brought by the First Industrial Revolution. In 1761 it was possible to enamel the internal part of a castiron container for the first time in history. At that time, the only method to deposit enamel on large cast-iron pieces consisted in heating to redness the metallic substrate and apply the powder enamel onto the hot surface, making it soft and adhering to the substrate. After this step, the piece was reheated in the furnace to make the enamel melt and create a smooth glassy surface [1]. This method, also if somewhat simple, is still used for the enamelling of large castiron pieces, such as bath tubes.

The real turning point for technical enamelling came around the 1850 when Austrian and German chemists successfully managed to enamel the internal part of sheet steel containers. It was in these years, to be precise in 1851, that the first manual on enamelling was published, written by Moritz Vogelsang [16]. Many technological advances helped the enamel industry to grow and prosper: among them, it is possible to mention 1) the development of the iron technology, 2) the discovery of the Solvay soda process, 3) the discovery of the Sassfurt salt deposits in $1856,4)$ the discovery of new stable pigments. In addition to that, one of the greatest boons to the enamelling industry was the discovery of clay to keep the powder enamel in suspension in water. This invention made it possible to use these suspensions, called "slips" (or torbida), to apply the enamel on steel pieces by a wet method. Nowadays, these techniques are still used, but many others have been developed, as, for example, the wet spray method (using spray guns, developed in the late 1970s) and the electrostatic powder method (a dry process used to enamel both cast iron 
and steel) [1][2].

From the beginning of the $20^{\text {th }}$ century, the use of enamelled objects spread rapidly in America, gaining more and more market through the years. From the last years of World War, I onward the industry of enamel boomed and attracted expert chemists, engineers and ceramists, who played a key role in transforming the old art of enamelling in a real science.

At the same time American industrialist recognized the interesting opportunities that the development of enamelling techniques would have given to many application fields: for this reason, the Porcelain Enamel Institute was founded in 1930 in America, and the Institute of Vitreous Enamellers was founded in 1934 in Europe [1].

The enamel industry rapidly grew after the Great Depression, as the demand of enamelled household objects, washing machines, stoves and refrigerators and hot water heaters grew many times. The low cost of enamelled items made them very popular among all the American families, and it is possible to state that around the 1950s all families had many enamelled objects in their houses.
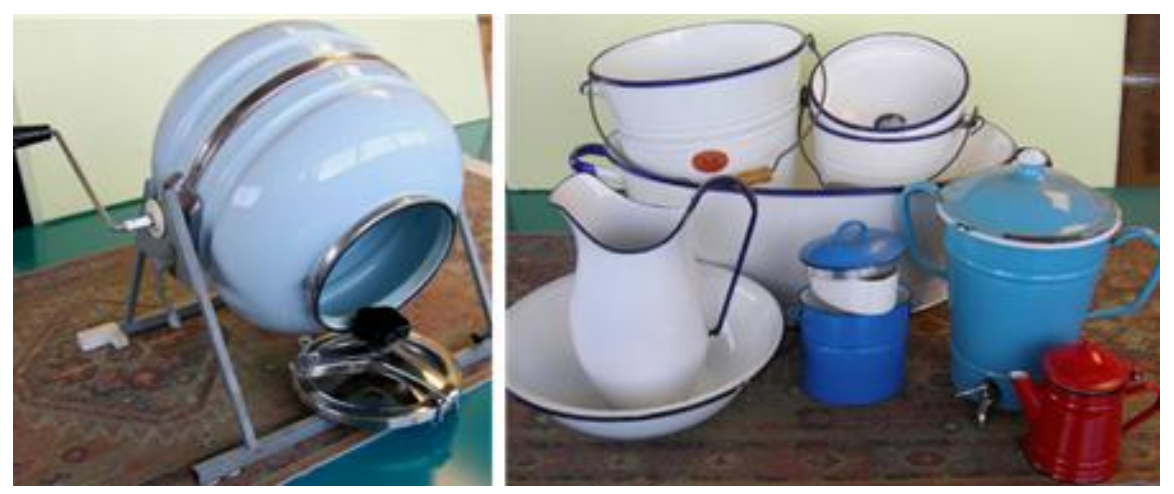

Figure 5: Enamelled washing machine (on the left) and enamelled products for household appliance (on the right) 1940's - 1950's. Conserved at Enamel Museum ArTchivio located in Ponte San Pietro (BG, Italy).

After the II World War, the production of enamelled household objects was flanked by the production of high-duty technological items, such as chemical reactors, flue pipes, and heat exchangers [1]2][19].
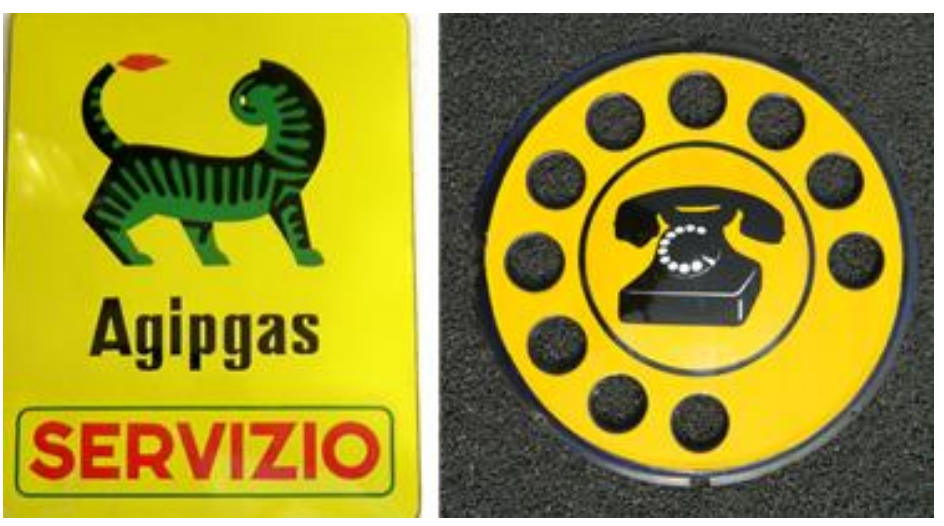

Figure 6: Enamelled metal nameplates, 1970's (on the left) and 1950's (on the right). Conserved at Enamel Museum ArTchivio located in Ponte San Pietro (BG, Italy).

Since the 1960s, with the advent of plastic, enamel has retained its importance but has been forgotten for simple applications, such as kitchenware and stoves, being mainly used for high-duty industrial applications. Today, enamel coatings are appreciated for technological purposes, as they guarantee optimal corrosion protection to the covered substrates, and they are able to withstand chemical attack, weathering and hot temperature environments ${ }^{[2]}$. 


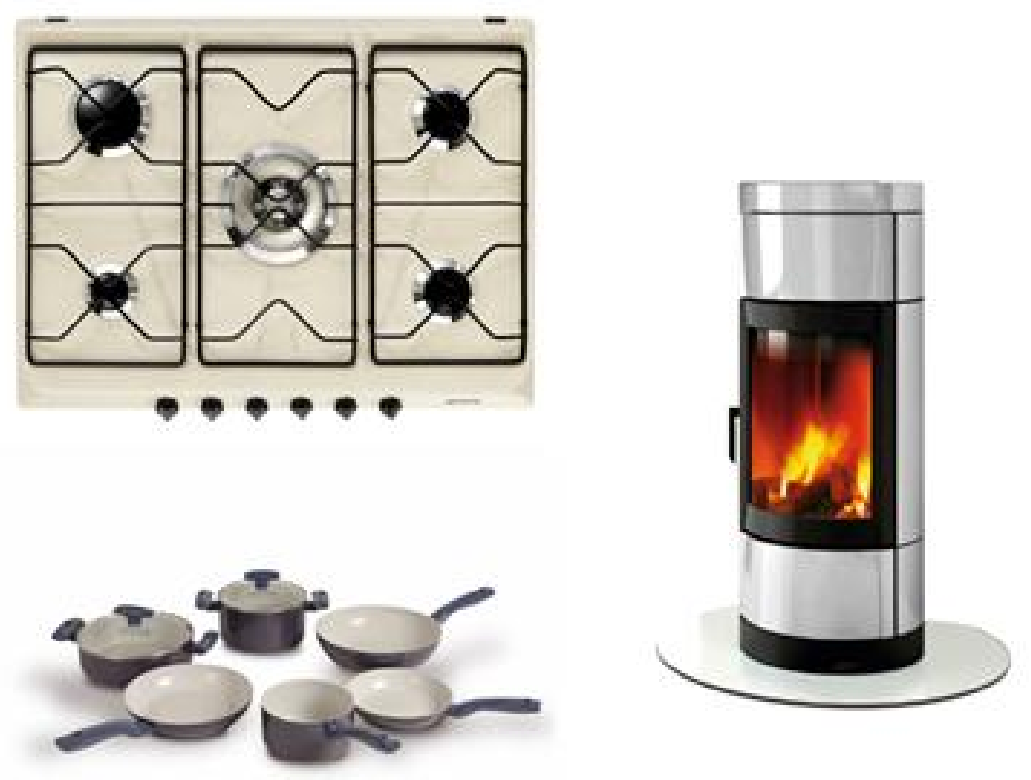

Figure 7: Enamelled aluminium pots, burner and hob.

In addition to that, enamel coatings maintain their aesthetical properties unchanged in time, also if subjected to aggressive environments. Several examples can be cited in applications in architecture, road and subway infrastructures. Thus, the combination of their functional and aesthetical properties makes enamel coatings of great interest both for industry and academia, as many unexplored applications could be discovered in the near future.

\section{Acknowledgements}

A grateful thanks to the C.K.I. team for useful information and discussion.

\section{References}

1. A.I. Andrews, S. Pagliuca, W.D. Faust Porcelain (Vitreous) Enamels and Industrial Enamelling Processes (third ed.), IEI, Mantova, Italy (2011)

2. A. Umbertazzi, N. Wojciecjowski Vitreous Enamel, Ulrico Hoepli Editore, Milano, Italy (2002)

3. A.H. Dietzel, Emaillierung, Springer-Verlag, Berlin, Germany (1981).

4. A. Petzold, H. Poeschmann Email und Emailliertechnik, Deutscher Verlag fuer Grundstoffindustrie, Leipzig, Germany (1986)

5. C. Riccardelli Egyptian Faience: Technology and Production, In: Heilbrunn Timeline of Art History. New York: The Metropolitan Museum of Art, 2000.

6. P.T. Nicholson Egyptian Faience and Glass, Shire Publications, Buckinghamshire (1993).

7. K. Charles Kiefer, A. Allibert Pharonic Blue Ceramics: The Process of Self-glazing, Archaeology 24 (1971): 107-17

8. H.G. Maryon Metalwork and Enamelling (5th edition), Dover Publications, New York, US (1971).

9. P. Michaelidis The earliest Cloisonné enamel from Cyprus, Glass on Metal 8 (2) (1989)

10. P.T. Nicholson, I. Shaw Ancient Egyptian Materials and Technology, Cambridge University Press, Cambridge, UK (2000).

11. P.R.S. Moorey Ancient Mesopotamian Materials and Industries: The Archaeological Evidence, Clarendon Press, Oxford (1994).

12. V. Gonzalez Gli smalti dell'Europa musulmana e del Maghreb, Jaca Book, Milano, Italy (1994).

13. N. López-Ribalta, E. Pascual i Miró La smaltatura a fuoco dei metalli, II Castello, Milano, Italy (2011).

14. F. McIntosh A study into Romano-British enamelling - with a particular focus on brooches, The School of Historical Studies Postgraduate Forum E-Journal Edition 7 (2009).

15. B. de Chancel, B. Drake Boehm, B. Barrière, E. Taburet, I. Biron, J. Becquet, M-M. Gauthier, M.T. Wypyski, M. Pastoreau, P. Dandrige Enamels of Limoges 1100-1350, The Metropolitan Museum of Art, New York, US (1996).

16. S. Rossi, E. Scrinzi, A.M. Compagnoni, A. Gallucci, Y. Gjata Enamel and design. The Potential of enamelled materials, Fausto Lupetti Editore, Bologna, Italy (2011).

17. S. Caroselli The Painted Enamels of Limoges: a catalogue of the collection of Los Angeles County Museum, LACMA/Thames \& Hudson, London, UK (1993).

18. www.cki.altervista.org/artchivio-museum.html

19. S. Rossi, F. Russo, Porcelain enamel coatings, from the past to the future: solved and unsolved issues for the improvement of their 
mechanical properties, Encyclopedia 2020. htps://doi.org/10.32545/encyclopedia202005.0001.v1

\section{Keywords}

porcelain enamel; enamel coatings; technical enamelling

(c) (i) (C) 2020 by the author(s). Distribute under a Creative Commans CC BY license 